\title{
To Customize or Not? Contextual Factors and High Performance Work Systems: A Literature Review
}

\author{
N. W. K. D. K. Dayarathna \\ Senior Lecturer \\ Faculty of Management Studies and Commerce \\ University of Sri Jayewardenepura \\ dushar@sjp.ac.lk
}

\begin{abstract}
The burgeoning High Performance Work System (HPWS)literature shows that organizations that implemented HPWSs recorded remarkable success, especially in organizations in the Western world. While these studies are mostly Western-based and it will be interesting to find out whether the impressive results can be applied to non-Western settings since the contextual factors differ between Western firms and Asian firms. This conceptual paper explores the research findings with regard to the contextual impact on the implementation of HPWSs in the world. The paper may be valuable to those who are interested in understanding the phenomenon of contextual impact on the implementation of HPWSs in the world for research purposes.
\end{abstract}

Key Words: Asian Firms, Contextual Factors, High Performance Work Systems, Western Firms 


\section{Introduction}

Human Resource Management (HRM) is an indispensable universal consideration in managing an organization to achieve its vision, mission and goals. The bundle of HRM practices which is instrumental in making an average performing organization to become a high performing organization is considered as HPWSs (Dayarathna, 2018 and 2012; Opatha, 2019). Amidst the increasing globalization there has been an increasing interest in whether, how and why HPWS policies and practices vary between countries. As Rosenzweig and Nohria (1994) stated that HRM is the area of management most likely to be subject to national differences. In recent years much of this interest has focused on aspects of national contexts in order to understand and explain the implications of economic, cultural, political, legal and technological factors on the implementation of HPWSs.

\section{Purpose Statement}

This conceptual paper is intended to identify and understand the contextual impact on the implementation of HPWSs in the world. Therefore, the inquiry question for this paper is: What are the implications of economic, cultural, political, legal and technological factors on the implementations of HPWSs in the world? The answer to the inquiry question was based on an extended review and analysis of literature.

\section{Methods for Collecting Literature}

This conceptual paper is based solely on a review and analysis of research from the existent literature. Since the topic deals with HPWSs, the method for collecting literature was using HRM databases. The most helpful databases were ABI/INFORM Complete (ProQuest), Business Source Complete (EBSCO), Emerald Insight, ProQuest Business, Sage Journals Online, Science Direct (Elsevier), and Wiley Online Library, where a number of articles were deemed useful for the topic of contextual factors and HPWSs.

\section{Findings from Literature}

\section{The Impacts of National Contexts on High Performance Work Systems}

The notion of HPWSs which originated in the manufacturing sector of United States (US) spearheaded across the service sector as US firms expanded in a globalized environment (Batt, 2002; Werner, 2011). Further, due to the rise of 'offshoring' to low cost producing countries such as China and India, HPWSs gained popularity across the world (Boxall, 2012).

When we move from any one national context, we have to consider the socio-cultural variations in HPWSs/HRM practices. For example, according to Huselid (1995), in the US employee grievance procedure is considered as a high performance indicator while in other countries (e.g., in UK) it is a legal requirement. Boselie, Paauwe, and Jansen (2001) state that some HPWS practices in the US are the institutional requirements. From Boxall and Macky's (2009) point of view legal differences are the more straightforward aspects of sociocultural variations and their underpinning cultural assumptions, such as attitudes to authority, 
gender, community and time, which are much more challenging. According to Trompenaars and Hampden-Turner (1997), some practices which may work well in the Anglo American world are understood quite differently and much less positively in less individualist or more hierarchical cultures. As Lawler, Chen, Wu, Bae, and Bai (2011) reported, while the US is an "at-will-employment" country, many other countries limit discharge at the employer's discretion. In many countries, permanent rank-and-file employees cannot be discharged except for cause or in the case of company closure. Such policies make it difficult to operationalize many aspects of HPWSs.

Lawler et al (2011) examined the implementation of HPWSs in 217 subsidiaries of Americanbased multinational enterprises (MNE) operating in 14 countries in Asia, Africa, and Europe. The findings of this study are very significant since it examined the impacts of the contextual factors on the implementation of American styled HPWSs in the host countries. According to their findings, the political-legal environment appears to exert a modest impact on HPWS implementation for rank-and-file employees, but not managerial employees. Employment laws often focus on working conditions for lower-level employees, which may explain the presence of an effect for restrictive labor laws for rank-and-file employees, but not managers. However, state efficiency had a weak effect on rank-and-file employees, and the differences between workers and managers on this variable are not meaningful. Most importantly, these results indicate that companies can expect less success in implementing HPWSs for rank-and-file employees in countries that impose significant restrictions on hiring, discharge, compensation, and other aspects of the employment relationships. The hostcountry's rate of economic growth exerted a strong influence on HPWS implementation, showing positive effects on HPWS implementation for both rank-and file employees and managers. Again, this effect was stronger in the case of rank-and-file employees. Subsidiaries operating in rapidly emerging economies integrated with the global market were highly prone to HPWS implementation. These results confirm the findings of Bjorkman, Fey, and Park (2007), who observed MNE subsidiaries in Russia. According to their findings, MNE subsidiaries were more inclined to employ HPWS approaches than MNE subsidiaries in the US. This study suggests that high-growth economies may act as incubators for HPWSs at least in the context of MNE subsidiaries. The most important finding of their study is that companies entering high-growth markets are likely to find an environment conducive to HPWS implementation.

According to Lawler et al (2011), per capita spending on education was strongly and positively related to HPWS implementation for rank-and-file employees. This effect appears in both advanced economies, where the general level of education is high, and in emerging economies that have invested heavily in education and training. Not only are skilled workers better prepared to take on the responsibilities associated with HPWSs, but they may also be more psychologically able to face the challenging work opportunities and stress that may be associated with HPWSs. The level of the host-country's economic development (i.e., per capita income) was not positively related to HPWS implementation for managers, but, contrary to expectations, was significantly and negatively related to HPWS implementation for rank-and-file employees (Lawler et al, 2011). Some of the higher income host countries in 
this study may have social environments that are less welcoming to HPWSs, or at least to the American model (i.e., Germany, Italy). In Western Europe, the quality of-life considerations in the values systems of workers often trump the pursuit of greater wealth and affluence. As a result, the level of economic development may be in part a proxy for social and cultural effects, and especially the weight that workers attach to higher income vs. quality of work life, which this model does not otherwise measure. American-style HPWSs may provide the potential for a substantially greater income, but for workers who are already affluent this may not be sufficient motivation, especially in light of the stresses and uncertainties of HPWSs (e.g., at-risk pay, merit based advancement etc.).

As Boxall and Macky (2009) stated, the in-depth industry studies show that there are specific industry context in which there is a positive relationship between HPWSs and OP (e.g., automobile, manufacturing and steel production). However, the authors further explain "one would have to be more cautious about apparel and toy manufacturing industries because of the quantum differences in labour costs between high-wage and developing countries in this low-tech, labour incentive industry" (Boxall and Macky, 2009, p.16). Boxall and Macky's (2009) argument is not surprising since much of the apparel and toy manufacturing which work very cost effectively on classical management principles of labour specialization without much worker empowerment (Boxall and Macky, 2007). From Delbridge's (2007) point of view, HPWSs are not suitable for lean, downsized organizations. As Boxall and Macky (2009) stated, HPWSs are a system of HRM practices oriented to a particular group of employees. Furthermore, Boxall and Macky (2009, p.11) argue that "HPWS studies which constitute some kind of argument about context free best practice are fatally flawed". Therefore, HPWS practices used to bring about higher employee involvement and participation need to be adapted to industry and occupational conditions.

Although some Asian countries were studied to link HPWSs to organizational performance (e.g., Casperze, 2006; Chow, Teo, and Chew, 2013; Chow, 2005; Chuang and Liao, 2010; Lawler et al, 2011), most of those studies used the western high performance work practices or focused exclusively on foreign subsidiaries heavily influenced by their western counterparts. Compared to other countries in the West, only a small number of studies have explored the impacts of HPWSs on organizational performance in Asia (Wickramasinghe and Gamage, 2011). Wickramasinghe and Gamage (2011, p. 517) have noted that:

"The picture is, however, unclear for Asian developing economies. Only a small number of empirical studies have explored employee involvement work practices ... in Asian countries .... Therefore, there is a need to explore employee involvement work practices ... in different industrial sectors in different parts of the world. Such studies will provide useful information for practitioners and academics alike, and consequently, could be the basis for further research of both a qualitative and quantitative nature."

Work systems and employment practices vary significantly across occupational hierarchical, work place, industry and societal context (e.g., Kalleberg Marsden, Reynolds, and Knoke, 2006). As stated by Boxall (2012) and Boxall and Macky (2009), any approach that 
aggregates a some kind of consensus around systems of "best practices" without regard to a specific context are therefore fundamentally false and not defensible. To make genuine theoretical progress in HPWS research, researchers must therefore go beyond the construction of lists of HRM practices and seek to identify the process and mediating variables which a set of practices is supposed to influence (Guest, 2011).

\section{HPWS Research in Sri Lanka}

Sri Lanka was one of the first developing countries to understand the importance of investing in HRM. As a result, it has a fairly well-developed HR base and has achieved human development outcomes more consistent with those of higher income countries (Chandrakumara and Budhwar, 2005). Both the Sri Lankan government and private sector organizations have recognized the importance of the role HRM plays in the nation's growth and in achieving a sustainable competitive advantage in the global marketplace (Chandrakumara and Budhwar, 2005). However, the scarcity of research on HRM practices in Sri Lankan organizations limits the ability to see the big picture on the contribution of HRM practices on organizational performance in the Sri Lankan context (Cooray and Dayarathna, 2017; Opatha, 2009; Wickramasinghe and Gamage, 2011). To date, there has been little discussion about how HPWS is understood, interpreted, and implemented in Sri Lankan organizations (e.g., Caspersz, 2006; Wickramasinghe and Gamage, 2011). Compared to other leading countries in the Asian region, only a small number of researchers have explored the impact of HPWS practices on organizational performance in Sri Lanka (Wickramasinghe and Gamage, 2011). The picture of the implementation of HPWSs in Sri Lankan organizations is ambiguous because of the lack of research done on the relationship between HPWSs and organizational performance.

\section{Conclusion}

What can we justifiably conclude about the contextual impacts of HPWSs? Should we customize HPWSs to the context? As stated by Boxall (2012), any approach that aggregates a some kind of consensus around systems of "best practices" without regard to a specific context is fundamentally false and not defensible and therefore we should customize HPWSs to the context. Moreover, the findings from this review will potentially facilitate future research on the comparison of HPWSs and its impact on organizational performance in Asia as well as in the West. Researchers can contribute to the HPWS literature when they help other researchers and managers to understand the applicability of different work systems in different contexts.

\section{References}

Batt, R. (2002), Managing customer services: Human resource practices, quit rates, and sales growth, Academy of Management Journal, Vol. 45, No.3, pp. 587-597.

Bjorkman, I., Fey, C.F., and Park, H.J. (2007), Institutional theory and MNC subsidiary HRM practices: evidence from a three-country study, Journal of International Business Studies, Vol. 38, pp. 430-446. 
Boselie, P., Paauwe, J., and Jansen, P. (2001), Human resource management and performance: Lessons from the Netherlands, The International Journal of Human Resource Management, Vol. 12, No.7, pp. 1107-1125.

Boxall, P. (2012), High- performance work systems: What, why, how and for whom?, Asia Pacific Journal of Human Resources, Vol. 50, pp.169-186.

Boxall, P. and Macky, K. (2009), Research and theory on high- performance work systems: Progressing the high-involvement stream, Human Resource Management Journal, Vol. 19, No.1, pp. 3-23.

Boxall, P. and Macky, K. (2007), High Performance Work Systems and Organizational Performance: Bridging Theory and Practice, Asia Pacific Journal of Human Resources, Vol. 45, No.3, pp. 261-270.

Caspersz, D. (2006), The 'Talk' versus the 'Walk': High performance work systems, labour market flexibility and lessons from Asian workers, Asia Pacific Business Review, Vol. 12, No.2, pp.149-161.

Chandrakumara, A. and Budhwar, P.S. (2005), Doing business in Sri Lanka, Thunderbird International Business Review, Vol. 47, No.1, pp.95-120.

Chow, I.H., Teo, S.T.T. and Chew, I.K.H. (2013), HRM system and firm performance: The mediating role of strategic orientation, Asia Pacific Journal of Management, Vol. 30, pp.53-72.

Chow, I.H. (2005), High performance work systems in Asian companies, Thunderbird International Business Review, Vol. 47, No.5, pp.575-599.

Chuang, C. and Liao, H. (2010), Strategic human resource management in service context: Taking care of business by taking care of employees and customers, Personnel Psychology, Vol. 63, pp.153-196.

Cooray, V.K.M. and Dayarathna, N.W.K.D.K. (2017), Aligning high performance work systems with internal organizational context: Case studies from Sri Lankan IT companies, Sri Lankan Journal of Human Resource Management, Vol. 7, No.1, pp.35-58.

Dayarathna, N.W.K.D.K. (2018), High performance work systems in the service sector: A Literature Review, Sri Lankan Journal of Human Resource Management, Vol. 08, No.1, pp. 52-59.

Dayarathna, N.W.K.D.K. (2012), Do high performance work systems pay off in Asia? Proceedings, Annual research sessions, International Conference on Business Management, Sri Lanka.

Delbridge, R. (2007), HRM and contemporary manufacturing, In Boxall, P., Purcell, J., and Wright, P. 2007, The Oxford handbook of human resource management (1st ed.), New York, Oxford University Press.

Guest, D. E. (2011), Human resource management and performance: Still searching for some answers, Human Resource Management Journal, Vol. 21, No.1, pp.3-13.

Huselid, M.A. (1995), The impact of human resource management practices on turnover, productivity and corporate financial performance, The Academy of Management Journal, Vol. 38, No.3, pp. 635-672.

Kalleberg, A., Marsden, P., Reynolds, J., and Knoke, D. (2006), Beyond profit? Sectoral differences in high- performance work practices, Work and Occupations,Vol.33, No.3, pp. 271-302. 
Lawler, J.J., Chen, S., Wu, P., Bae, J. and Bai, B. (2011), High- performance work systems in foreign subsidiaries of American multinationals: An institutional model, Journal of International Business Studies, Vol. 42, pp. 202-220.

Macky, K. and Boxall, P. (2008), High-involvement work processes, work intensification and employee well-being: A study of New Zealand worker experiences, Asia Pacific Journal of Human Resources, Vol.46, No. 1, pp. 38-55.

Opatha, H.H.D.N.P. (2019), Sustainable Human Resource Management, Department of HRM, University of Sri Jayewardenepura, Colombo.

Opatha, H.H.D.N.P. (2009), Human Resource Management, Department of HRM, University of Sri Jayewardenepura, Colombo.

Rosenzweig, P.M., and Nohria, N. (1994), Influences on human resource management in multinational corporations, Journal of International Business Studies, Vol. 20, No.2, pp. 229-251.

Trompenaars, F. and Hampden-Turner, C. (1997), Riding the waves of culture: Understanding culture diversity in business, London, Nicholas Brealey Publishing.

Werner, S. (2011), High performance work systems in the global context: A commentary essay, Journal of Business Research, Vol.64, No. 8, pp.919-921.

Wickramasinghe, V. and Gamage, A. (2011), High involvement work practices, quality results, and the role of HR function: An exploratory study of manufacturing firms in Sri Lanka, The TQM Journal, Vol.23, No. 5, pp.516-530. 